Al-Fikra: Jurnal Ilmiah Keislaman, Vol. 7 , No. 2, Juli-Desember 2008

\section{FILOSOFIS FIKIH RASIONAL DALAM ISLAM}

\section{Khairuddin}

Program Pascasarjana UIN Suska Riau

E-mail: kh4iruddin@yahoo.co.id.

\section{Abstract}

The Philosophy of Rational Fiqh in Islam: When the Prophet Muhammad (Peace be up Him) was still alive, the shohabats' were not interested in talking about philosophy or details and meticulous explanation. They learned ablution, did prayers, went to Makkah for Hajj, paid 'qakat' and dealt with other religious components by following what was done by the Prophet. They also did not classify which parts of the Prophet's behavior that contained arkan (rukun-rukun) and nadab (sunat). When were cases, they came to the Prophet and asked for his advice for decisions. After the Prophet passed away, the expansion of Islam territory was great; as a result people were faced with various traditions, cultures, and complicated problems that needed solving. In overcoming the problems a character was found that colored the thinking model in handling the Islamic laws which is more known as 'Rational Figh'. This 'rational figh' was born because of such factors as intellectual legacy, structural and cultural factors.

Keywords: Islamic laws, Rational Fiqh

\section{Pendahuluan}

Ketika rasulullah saw. masih hidup, sesuai dengan posisinya sebagai rasul dan pemimpin umat, para sahabat tidak mendapatkan kesulitan yang berarti bila ada kasus hukum yang akan diselesaikan. Mereka dapat merujuk langsung kepada nabi sebagai jalan penyelesaiannya. Dalam menyelesaikan persoalan tersebut kadang kala
Khairuddin, Filosofis Fikih Rasional dalam Islam

nabi menunggu wahyu sebagai jawabannya. ${ }^{1}$ Nabi juga pernah menyelesaikannya sendiri ${ }^{2}$ dan bahkan terkadang melibatkan sahabat. ${ }^{3}$

Keadaan menjadi berubah setelah rasulullah saw. wafat, daerah kekuasaan Islam bukan lagi sebatas Hijaz, tetapi telah meluas ke berbagai daerah. Dengan meluasnya daerah kekuasaan Islam tersebut, dengan sendirinya umat berhadapan dengan berbagai tradisi, budaya dan permasalahan yang makin komplit dan selama di Hijaz belum pernah ditemukan, sementara nabi tidak ada lagi bersama mereka, di sisi lain permasalahan demi permasalahan harus diselesaikan. Dalam

${ }^{1}$ Banyak sekali kasus hukum yang diselesaikan nabi dengan cara menunggu wahyu sebagai jawabannya, di antaranya ketika nabi ditanya tentang apa itu darah haidh dan bagaimana tindakan seorang suami kepada isterinya yang sedang haidh ?. Pertanyaan ini langsung dijawab nabi dengan membacakan ayat 222 surat alBaqarah:

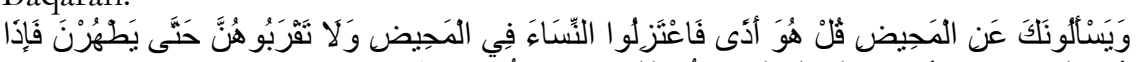

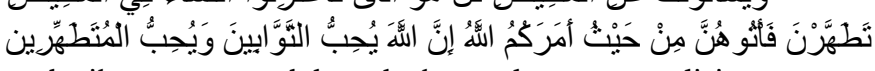

2 Ketika nabi menyeleaikan permasalahan hukum dengan sendirinya tanpa menunggu wahyu yang akan menyelesaikannya, keputusan nabi boleh jadi benar dan boleh jadi salah. Di saat nabi benar, maka tidak ada wahyu yang mengkomplinnya, namun bila keputusan nabi tersebut salah, maka mendapatkan teguran dari Allah SWT. Sebagai contoh keputusan nabi dalam menyelesaikan persoalan dengan sendirinya meskipun hal demikian kemudian mendapat teguran dari wahyu. Hal ini dapat dilihat kasus perang Tabuk, beberapa orang prajurit Islam datang menghadap rasulullah saw dan menyatakan bahwa mereka tidak siap untuk melaksanakan jihad dengan mengemukakan beberapa alasan. Dalam hal ini dengan ijtihadnya, nabi memperkenankan mereka dan menerima alasan yang mereka kemukakan. Tetapi Allah memperingatkan nabi karena ternyata di antara mereka

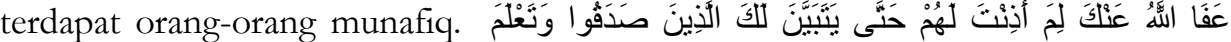
. Q.S. al-Taubah: 43.

3 Ijtihad nabi Muhammad saw yang melibatkan sahabat dapat dilihat pada kasus "tawanan Badar". Pada waktu itu belum ada nash yang mengatur bagaiman perlakuan terhadap tawanan perang. Dalam kondisi seperti itu nabi meminta pendapat Abu Bakar dan Umar. Umar ibn al-Khattab mengusulkan supaya tawanan perang Badar tersebut dibunuh, karena hal itu lebih mendatangkan maslahat. Sementara Abu Bakar mengusulkan supaya diambil saja tebusan dari mereka karena selain menambah income juga mereka itu masih saudara sendiri. Nabi memilih pendapat Abu Bakar, lalu kemudian turun ayat al-Qur'an yang membenarkan pendapat Umar ibn al-Khattab. Hal ini dapat dilihat pada surat alAnfal ayat 63. 
Al-Fikra: Jurnal Ilmiah Keislaman, Vol. 7, No. 2, Juli-Desember 2008

penyelesaian persoalan tersebut terdapat dua karakter yang mewarnai model berpikir dalam penyelesaian hukum Islam yang di generalisasikan dalam sejarah perkembangan hukum Islam dengan istilah fikih Hijaz dan Irak.

Dalam tulisan ini penulis hanya mengungkapkan secara filosofis munculnya kubu fikih Irak atau biasa disebut fikih rasional, serta menjelaskan bagaimana karakter berpikir mereka. Semoga dapat menjadi bahan awal dalam memperdalam analisa berikutnya.

\section{Pengertian Fikih}

Fikih merupakan kosa kata Arab (fiqh) yang berasal dari faqibayafqahu-fighan. Secara ethimologi berarti pengertian dan faham yang mendalam. ${ }^{4}$ Penggunaan kata fiqh dan yang seakar dengannya dalam al-Qur'an terdapat pada 20 tempat. Menurut Rasyid Ridha 19 di antara ayat-ayat tersebut berarti kedalaman faham. ${ }^{5}$ Untuk melihat kebenaran tersebut dapat dilihat kata fiqh yang terdapat pada ayat 122 surat alTaubah.

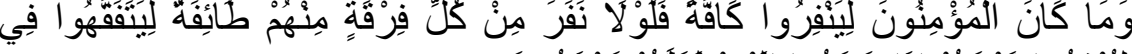

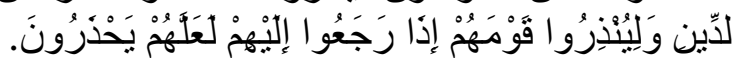

"Tidak sepatutnya bagi orang-orang yang mu'min itu perg semuanya (ke medan perang). Mengapa tidak pergi dari tiap-tiap golongan di antara mereka beberapa orang untuk memperdalam pengetahuan mereka tentang agama dan untuk memberi peringatan kepada kaumnya apabila mereka telah kembali kepadanya, supaya mereka itu dapat menjaga dirinya”.

Pada ayat tersebut jelas terlihat bahwa kata kerja yatafaqqahu menunjukkan kedalaman faham mengenai ajaran agama. Ketika menafsirkan ayat di atas, Qurtubi menulis bahwa ayat ini menjadi dasar bahwa memperdalam pengetahuan tentang kandungan al-Qur'an

4 Ahmad Warson Munawwir, Kamus Al-Munawwir, (Surabaya: Pustaka Progresif, 1997), hlm. 1067

${ }^{5}$ Muhammad Rasyid Ridha, Tafsir al-Qur'an al-Halim, jilid IX, (Beirut: Daar al-Ma'arif, t.th), hlm. 420
Khairuddin, Filosofis Fikih Rasional dalam Islam

dan sunnah rasulullah saw hukumnya fardhu kifayah. ${ }^{6}$ Ibn Katsir juga sepakat dengan apa yang diungkapkan oleh Qurtubiy. ${ }^{7}$

Adapun pengertian fikih menurut terminologi, banyak dikemukakan oleh tokoh, antara lain adalah:

1. Imam Abu Hamid al-Ghazali

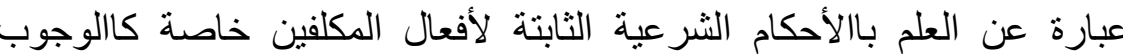

و الحظروالإباحة و الندب و الكرهة وكون العقد صحيحا وفاسدا وباطلا وكون العبادة

قضاء و اداء ومااشبه ذاللك ولن

Suatu ilmu yang menerangkan bukum-bukum syara' yang tertentu bagi perbuatan-perbuatan para mukallaf, seperti wajib, haram, mubah, sunat, makruh, syah, fasid batal, qadha', dan yang sepertinya. ${ }^{8}$

\section{Al-Mahalli}

$$
\text { الأحكام الثرعية العملية المكتسبة من ادلتهاالتفيلية }
$$

Hukum-hukum syara' yang berhubungan dengan amaliyah praktis yang diusahakan memperolehnya dari dalil-dalil yang jelas.

3. Imam Ibn Hazm

هو معرفة بأحكام الثريعة من القرآن ومن كلام المرسل بها الذى لاتؤخذ الاعنه. Yaitu pengetahuan tentang bukum-bukum syara' yang diambil dari alQur'an dan dari kalam rasul yang diutus membawa syari'at yang banya daripadanya bukum-bukum itu. ${ }^{9}$

Berdasarkan informasi tersebut, maka dapat dipahami bahwa fikih itu merupakan suatu ilmu yang dengan ilmu-ilmu tersebut kita mengetahui hukum-hukum syar'i yang amaliyah yang diperoleh dari dalil-dalilnya yang bersifat tafsil.

${ }^{6}$ Abu Abdillah Muhammad ibn Ahmad al-Anshariy al-Qurtubiy, Al-Jami' li Abkam al-Qur'an, Jilid 4, Juz 8, (Beirut: Daar al-Fikr, 1994), hlm. 187

Al-Hafidz Imaduddin Abu al-Fida' Ismail ibn Katsir, Tafsir al-Qur'an al'Azbim, Jilid 2, (Cairo: Maktabah Mishr, 1990), hlm. 409

8 Abu Hamid Muhammad ibn Muhammad al-Ghazali, Al-Mustashfa min ilm al-Ushul, (Beirut: Daar al-Fikr, t.th.), jilid 1, hlm. 4-5

9 Abu Muhammad Ali ibn Ahmad ibn Sa'id ibn Hazm, Al-Ibkam fi Ushul alAhkam, (Beirut: Daar al-Kutub al-Ilmiah, t.th), jilid 2, hlm. 121 
Al-Fikra: Jurnal Ilmiah Keislaman, Vol. 7, No. 2, Juli-Desember 2008

Pada masa rasulullah saw istilah "fikih" tidak hanya digunakan dalam pengertian hukum saja, tetapi mempunyai arti yang lebih luas dan mencakup semua aspek dalam Islam, baik teologi, politik, ekonomi dan hukum. Alasan terjadinya perubahan ini adalah jelas sekali, karena persoalan masyarakat muslim semasa hidup rasulullah saw tidaklah sedemikian pelik dan beraneka ragam sebagaimana tumbuh kemudian. Pembauran kaum muslim dengan non-muslim di daerah-daerah taklukan, munculnya beberapa mazhab hukum dan teologi dalam Islam, serta perkembangan ilmu keislaman merupakan faktor-faktor utama yang menyebabkan perubahan arti beberapa istilah dalam Islam (khususnya kosa kata fiqh) yang sederhana dan tidak pelik sebagaimana yang dipahami kaum muslimin pada masa rasulullah saw. ${ }^{10}$

Sebagai bukti bahwa "fikih" bukan hanya digunakan untuk kajian hukum-hukum Islam semata, diceritakan bahwa rasulullah saw pernah mendo’akan Ibn Abbas اللهم فقهه فى الدين ya Allah berikanlah dia kepahaman yang mendalam tentang ajaran agama". Dengan do'a ini jelas bahwa yang dimaksud oleh rasulullah saw tentunya bukan hanya kepahaman tentang hukum-hukum Islam semata, melainkan kepahaman dalam seluruh komponen ajaran agama. Selain contoh di atas, juga dapat dipahami contoh lain, yakni diceritakan pada masa rasulullah saw. sejumlah orang Arab dusun (Badui) telah meminta kepada rasulullah saw. agar diutus seseorang kepada suku mereka untuk mengajari mereka masalah-masalah keagamaan. Permohonan mereka ini juga diungkapkan dengan kata "fikih" يفقهونتا فى الدين "11. Pada contoh ini juga dipahami bahwa penggunaan kata "fikih" adalah dalam arti yang luas, meliputi prinsip-prinsip Islam maupun hukumhukumnya. Karena dapat dipahami keinginan orang Arab dusun tersebut tentunya bukan saja masalah hukum semata, tetapi juga meliputi prinsip-prinsip Islam lainnya.

Setelah rasulullah saw wafat, kaum muslimin dihadapkan dengan persoalan-persoalan baru yang memaksa mereka menggunakan

${ }^{10}$ Ahmad Hasan, The Early Development of Islamic Jurisprudence, alih bahasa oleh Agah Garnadi, (Bandung: Pustaka, 1984), hlm. 2

${ }^{11}$ Ibid.
Khairuddin, Filosofis Fikih Rasional dalam Islam

pertimbangan pribadi. Pada tahap ini istilah fikih lalu sering digunakan dengan arti penggunaan kecerdasan. Penggunaan istilah fikih ini lebih jelas lagi pada akhir abad pertama Hijrah yang digunakan secara eksklusif bagi pengetahuan yang dilandaskan pada penggunaan kecerdasan dan pertimbangan yang independen. Pada tahun $94 \mathrm{H}$ dikenal sebagai sanat al-fuqaha (tahun para ahli fikih), karena sejumlah ahli fikih terkemuka di Madinah seperti Sa'id ibn al-Musayyab dan Abu Bakar ibn 'Abdurrahman wafat pada tahun tersebut.

Berdasarkan penjelasan di atas diketahui bahwa ruang lingkup istilah fikih secara bertahap menyempit yang akhirnya terbatas pada masalah-masalah hukum, bahkan lebih sempit lagi, yaitu pada literatur hukum. ${ }^{12}$ Dengan demikian, maka "fikih" yang dimaksud dalam kajian ini adalah hukum Islam yang ditetapkan melaui ijtihad.

\section{Lahirnya Fikih Irak (Ahl al-Ra'y)}

Pada paragraf awal dari tulisan ini telah diungkapkan bahwa ketika rasulullah saw masih hidup para sahabat tidak tertarik pada perbincangan filosofis ataupun rincian dan penjelasan yang njlimet yang menurut mereka tidak perlu. Bagi mereka, satu-satunya yang ideal hanyalah perilaku rasulullah saw. Mereka belajar wudhu', mengerjakan shalat, menjalankan haji, membayar zakat dan komponen ajaran agama lainnya cukup dengan mengamati bagaimana rasulullah saw. berbuat. Mereka juga tidak memilah-milah bagian mana dari tindakan-tindakan nabi yang mengandung arkan (rukun-rukun) dan mana pula yang mengandung syarat. Mereka juga belum memilah perbuatan rasulullah saw yang mana merupakan wajib, nadab (sunat) dan mana pula yang mubah. Apabila timbul kasus-kasus, hal itu diajukan kepada rasulullah saw. untuk dimintai keputusannya. Dalam menanggapi keputusan beliau, orang-orang di sekitarnya tak bertanya mengenai hal-hal khusus tentang hukum guna tujuan teoritis semata-mata; mereka mengambil

12 Untuk lebih jelasnya kronologis penggunaan kata fikih dalam perkembangan sejarah hukum Islam, dapat dilihat dalam; Ismail Muhammad Syah dkk, Filsafat Hukum Islam, (Jakarta: Bumi Aksara, 1992), hlm. 14 dan lihat juga Ahmad Hasan, The Early..., hlm. 4 
Al-Fikra: Jurnal Ilmiah Keislaman, Vol. 7, No. 2, Juli-Desember 2008

keputusan beliau sebagai model untuk mengambil keputusan serupa dalam kasus-kasus serupa.

Setelah rasulullah saw. wafat, para sahabat tersebar di berbagai pelosok dunia Islam. Umumnya mereka menduduki posisi kepemimpinan keagamaan dan intelektual. Mereka menjadi tempat orang bertanya di daerahnya untuk dimintai keputusan berkaitan dengan berbagai persoalan. Mereka memberikan keputusan kadangkadang berdasarkan apa yang pernah mereka pelajari dan ingat dari perintah-perintah rasulullah saw. dan di lain waktu menurut apa yang mereka pahami dari al-Qur'an dan sunnah. Mereka sering membentuk pendapat sendiri dengan melihat nilai syari'ah (illat) yang menuntun rasulullah saw untuk mengambil keputusan.

Suatu waktu, Ibn Mas'ud dikabarkan pernah ditanya apakah seorang wanita sepatutnya diberikan mahar jika suaminya mati sebelum menetapkan besar maharnya dan sebelum keduanya tidur bersama. Pada awalnya Ibn Mas'ud menjawab bahwa ia belum pernah mendengar sesuatu dari rasulullah saw mengenai permasalahan tersebut. Tetapi ketika ia diminta memberikan saran, ia berpendapat bahwa perempuan itu harus diberi mahar sebanyak rata-rata mahar seorang perempuan pada tingkat sosial yang sama. Lebih jauh ia menyarankan bahwa perempuan itu berhak menerima hak waris penuh dari warisan suaminya dan baginya ada iddah. Ma'qil ibn Sinan (w. $63 \mathrm{H}$ ) ketika itu dikabarkan hadir dalam peristiwa tersebut dan mengatakan bahwa rasulullah saw dahulu telah menetapkan keputusan yang sama.

Dalam permasalahan yang sama Ibn Umar (w. $73 \mathrm{H}$ ) dan Zaid Ibn Tsabit (w. $45 \mathrm{H}$ ) memberikan keputusan bahwa janda yang demikian tidak akan memperoleh mahar sedikitpun, tetapi hanya memperoleh bagiannya dalam hal warisan.

Orang-orang Irak mengikuti pendapat Ibn Mas'ud dan menolak keputusan Ibn Umar dan Zaid ibn Tsabit. Alasan pemilihan mereka barangkali ialah karena pandangan Ibn Mas'ud dinisbatkan kepada rasulullah saw, sedangkan pandangan Ibn Umar dan Zaid tidak. Bila dinyatakan bahwa kedua pendapat tersebut dilandaskan pada tradisi, maka tak satupun dari kedua pendapat yang bertentangan tersebut yang dapat dikatakan berasal dari tradisi rasulullah saw. Karena,
Khairuddin, Filosofis Fikih Rasional dalam Islam

andaikan ada ketetapan yang jelas dari rasulullah saw mengenai suatu masalah sosial yang demikian pentingnya seperti pernikahan, bagaimana mungkin perbedaan pendapat yang bertolak belakang seperti itu terjadi. Lebih jauh, seandainya orang-orang Irak mengklaim otoritas dari tradisi rasulullah saw, maka ketidaktahuan dua orang sahabat terkemuka seperti Ibn Umar dan Zaid ibn Tsabit akan tradisi rasulullah yang mereka klaim itu, akan menjadikan keotentikan tradisi tersebut diragukan, terutama karena masalah yang dipersoalkan adalah demikian penting, yaitu pernikahan. Sangat sulit dipercaya bahwa keputusan rasulullah saw dalam masalah yang demikian penting tetap tinggal sedemikian pribadinya dan tak tersiarnya, sehingga hanya diketahui oleh satu atau dua orang sahabat saja. Karena itu cara yang biasa untuk menjawab persoalan demikian, yakni dengan mengatakan bahwa hadis yang bersangkutan mungkin sekali tidak sampai pada sahabat-sahabat yang lain selain Ibn Mas'ud, tak dapat diterima.

Diduga kuat bahwa pendapat Ibn Mas'ud didasarkan pada pertimbangan kemaslahatan dan kondisi sosial masyarakat ketika itu, sehingga ia menetapkan kewajiban pemberian mahar sesuai dengan tingkat sosial yang sama, ini berarti Ibn Mas'ud menjadikan kebiasaan yang berlaku pada masyarakat tersebut sebagai acuan dalam penetapan jumlah maharnya, hal inilah yang kemudian disebut dalam landasan penetapan hukum Islam dengan 'urf al-shahih (tradisi dan kebiasaan baik yang berlaku dalam masyarakat tertentu). Selain itu juga tentunya ia berpegang bahwa pengertian pernikahan adalah aqd (transaksi ijab dan qabul), dengan demikian apabila telah dilangsungkan akad, maka timbullah konsekwensi hukum lainnya termasuk bagian terakhir yang disebutkannya perempuan tersebut berhak mewarisi dan berlaku pula baginya iddah seorang perempuan yang ditinggal mati suaminya.

Adanya fikih Hijaz juga disebabkan Hijaz merupakan tempat tinggal kenabian. Di situ rasulullah saw menetap, menyampaikan seruannya, kemudian para sahabat beliau menyambut, mendengarkan, memelihara sabda-sabda beliau dan menerapkannya. Kemudian Hijaz menjadi tempat tinggal banyak dari mereka (para sahabat) yang datang kemudian sampai beliau wafat. Kemudian mereka ini mewariskan apa saja yang mereka ketahui kepada penduduk berikutnya (generasi tabiin) yang bersemangat untuk tinggal di sana. 
Al-Fikra: Jurnal Ilmiah Keislaman, Vol. 7, No. 2, Juli-Desember 2008

Sedangkan Irak telah mempunyai peradabannya sendiri, sistem pemerintahannya, kompleksitas kehidupannya dan tidak mendapatkan bagian dari sunnah kecuali melalui para sahabat dan tabiin yang pindah ke sana. Sedangkan yang mereka bawa itupun masih jauh lebih sedikit jika dibandingkan dengan apa yang ada di Hijaz. Padahal peristiwa-peristiwa hukum yang ada di Irak disebabkan masa lampaunya adalah lebih banyak daripada yang ada di Hijaz; begitu pula kebudayaan penduduknya dan terlatihnya mereka pada penalaran, adalah lebih luas dan lebih banyak. Karena itulah keperluan mereka kepada penalaran lebih terasa dan penggunaannya juga lebih banyak. Penyandaran diri kepadanya juga lebih jelas nampak, mengingat sedikitnya sunnah pada mereka itu tidak memadai untuk semua tuntutan mereka. Ini masih ditambah dengan kecenderungan mereka untuk banyak membuat asumsi-asumsi dan perincian karena keinginan mendapatkan tambahan pengetahuan, penalaran yang mendalam dan pelaksanaan yang banyak. ${ }^{13}$

\section{Karakter Fikih Irak (Fikih Rasional)}

Telah dipaparkan tentang kecenderungan lahirnya fikih Irak dan Hijaz yang dilatarbelakangi oleh beberapa faktor yang antara lain; [a] merupakan warisan intelektual yang merera ikuti. Di Irak fuqaha' mewarisi metodologi rasional dari Ibn Mas'ud yang konon banyak terpengaruh dengan pemikiran-pemikiran Umar ibn al-Khattab. Ibn Mas'ud kemudian mewariskan metodologi pemikirannya kepada beberapa muridnya yang apresiatif seperti 'Alqamah, Masruq dan Suraih. Dari 'Alqamah ini, pemikiran rasional itu dikembangkan oleh Ibrahim an-Nakha'ie yang kemudian menjadi guru Imam Abu Hanifah yang terkenal sebagai pendiri fakultas abl al-ra'y. ${ }^{14}$ Berbeda dengan di Hijaz (khususnya Madinah) tokoh fikih yang terkenal dari tabiin adalah Sa'id ibn al-Musayyab yang belajar langsung dari Zaid ibn

${ }^{13 N u r c h o l i s h ~ M a d j i d, ~ S e j a r a h ~ A w a l ~ P e n y u s u n a n ~ d a n ~ P e m b a k u a n ~ H u k u m ~ I s l a m ~}$ dalam; Kontekstualisasi Doktrin Islam Dalam Sejarah , editor; Budhy Munawar Rachman, (Jakarta: Paramadina, 1994), hlm. 242-243

${ }^{14}$ Hudlory Bek, Tarikh al-Tasyri' al-Islamy, (Beirut: Daar al-Fikr, 1995), hlm.
Khairuddin, Filosofis Fikih Rasional dalam Islam

Tsabit, Abdullah ibn Umar dan Abdullah ibn Abbas. Sa'id ibn alMusayyab mengajarkan ilmunya kepada banyak muridnya antara lain yang terkenal seperti Muhammad ibn Muslim atau yang lebih dikenal dengan nama Ibn Syihab az-Zuhri yang kemudian banyak andil dalam membina Imam Malik ibn Anas yang selalu ditokohkan sebagai abl alhadis. ${ }^{15}$

Selain warisan intelektual, juga merupakan [b] faktor struktural, Irak yang nota bene merupakan tempat terjadinya konflik antara aliran teologi Syi'ah dan Khawarij. Dengan adanya dua aliran besar yang konfliks ini memicu munculnya kebohongan dan penyelewengan dalam periwayatan hadis. Hal ini tentunya memaksa fuqaha' Irak untuk melakukan seleksi yang ketat terhadap penerimaan riwayat hadis. Dengan demikian mereka lebih banyak menggunakan ijtihad karena memang hadis yang mereka terima hanya sedikit sekali. Keadaannya jauh berbeda jika dibandingkan dengan di Hijaz. Di Hijaz banyak hadis-hadis dan fatwa-fatwa sahabat sehingga mereka merasa tidak begitu perlu untuk melakukan ijtihad dan menggunakan rasio sebagaimana fuqaha' Irak. ${ }^{16}$

Lahirnya kubu Irak dan Hijaz ini juga bisa dilihat dari [c] faktor kultural, Irak merupakan daerah yang jauh dari bumi kenabian dan bumi hadis. Irak adalah daerah terbuka yang banyak mendapat pengaruh kebudayaan dan peradaban lain. Fuqaha' di daerah ini sering dihadapkan pada berbagai persoalan hidup berikut problematikanya yang beraneka ragam. Untuk mengatasi persoalan-persoalan tersebut mereka terpaksa melakukan ijtihad dan menggunakan rasio. Berbeda dengan di Madinah yang merupakan gudang ilmu Islam. Selain itu, masyarakat daerah ini masih diliputi oleh suasana kehidupan sederhana, seperti keadaan pada masa nabi Muhammad saw. Dengan demikian untuk mengatasi berbagai permasalahan dalam kondisi seperti ini fuqaha' merasa cukup dengan hanya mengandalkan

15 Muhammad Hasbi Ash Shiddieqy, Pengantar Hukum Islam I, (Jakarta: Bulan Bintang, 1980), hlm. 102. Lihat juga; Abdurrahman I.Doi, Syari'ab The Islamic Law, alih bahasa oleh Basri Iba Asghary dan Wadi Masturi, (Jakarta: Rineka Cipta, 1993), hlm. 148

${ }_{16}$ Mun'im A. Sirry, Sejarah Fiqih Islam Sebuah Pengantar, (Surabaya: Risalah Gusti, 1996), hlm. 59 
Al-Fikra: Jurnal Ilmiah Keislaman, Vol. 7, No. 2, Juli-Desember 2008

pemahaman literal terhadap al-Qur'an, sunnah dan ijma' sahabat. Karena itulah mereka tidak merasa perlu berijtihad seperti fuqaha' Irak. ${ }^{17}$

Berdasarkan penjelasan pada beberapa paragraf di atas, maka dapat dipahami karakter fikih Irak yang selalu dikatakan sebagai abl alra'y (mazhab rasionalisme) adalah lebih banyak menggunakan rasio dengan melakukan ijtihad ketimbang penggunaan hadis. Sedangkan fikih Hijaz atau juga yang sering disebut sebagai mazhab abl al-hadis atau abl al-riwayat (mazhab tradisionalisme) secara umum adalah dalam menyelesaikan persoalan lebih banyak merujuk pada hadis serta fatwafatwa sahabat dibandingkan penggunaan rasio dan melakukan ijtibad.

\section{Masa Depan Fikih Rasional}

Telah menjadi fakta historis bahwa mazhab fikih tradisional dan rasional eksis dan akan tetap eksis. Kenyataan ini dapat kita saksikan bagaimana kecendrungan masyarakat muslim dewasa ini terhadap hukum Islam atau lebih tepatnya fikih yang bisa diidentifikasi dalam bentuk: Pertama, fikih klasik masih merupakan prioritas utama sebagai bahan rujukan terhadap kasus-kasus hukum yang terjadi di masyarakat muslim, meskipun kesadaran intelektual mereka menyadari bahwa kitab-kitab tersebut disusun pada abad ke-2 Hijrah. Ini dipahami juga bahwa masa penyusunan kitab-kitab turats tersebut sudah mengalami rentang waktu sekitar dua belas abad. Kedua, masyarakat muslim masih lebih bersemangat mengamalkan fikih ibadah dibandingkan dengan fikih muamalah. Ketiga, sebagai akibat fanatisme terhadap prodak turats, akhirnya ijtihad dianggap sudah tertutup bagi masyarakat muslim hari ini.

Fenomena pertama jelas memiliki kelemahan baik dari segi metodologi maupun sosial kultural. Metode bayani menjadi metode yang representatif dalam menyusun kitab turats, dengan demikian argumen kebahasaan menjadi lebih dominan dibandingkan dengan pertimbangan sosial. Dari segi sosial kultural jelas memiliki perbedaan

${ }^{17}$ Huzaemah Tohido Yanggo, Pengantar Perbandingan Maz̧hab, Jakarta: Logos, 1997), hlm. 73
Khairuddin, Filosofis Fikih Rasional dalam Islam

yang cukup signifikan, ia disusun untuk konsumsi masyarakat Arab yang hidup di zaman agraris dengan kebudayaan yang jauh berbeda dengan masyarakat era informasi. Fenomena kedua menyebabkan pengagungan kepada sebahagian kandungan al-Qur'an dan sunnah rasulullah saw dan sekaligus sebagai perlakuan diskriminatif terhadap kandungan al-Qur'an dan sunnah lainnya, padahal sesungguhnya kandungan al-Qur'an dan sunnah merupakan satu kesatuan. Adapun fenomena ketiga bahwa sesungguhnya ijtihad tidak akan pernah tertutup, karena makin lama dan makin berkembang kebudayaan manusia maka makin tinggi pula kebutuhan manusia terhadap hukum. Ini tentunya tidak akan dapat diselesaikan kecuali melalui ijtihad.

Fikih Islam sebagaimana yang dikembangkan oleh ulama mujtahid masa lalu, ternyata tidak memenuhi seluruh kebutuhan masyarakat akan hukum. Hakikat fikih Islam tidaklah statis, tetapi sebaliknya menghendaki perkembangan. Pada masa lampau fikih memang berkembang. Hanya pernah terjadi dalam sejarah bahwa ijtihad sebagai sumber ketiga yang menjadi pendorong bagi berkembangnya fikih, pintunya dianggap tertutup pada abad ketiga belas Masehi. ${ }^{18}$

Ada beberapa tawaran pemikiran untuk pembaharuan fikih di dunia Islam. Di Indonesia, Munawir Sadzali pernah menawarkan konsep "reaktualisasi hukum Islam" dengan beberapa langkah kebijakan; pertama, kebijakan administratif, seperti perkawinan baru dianggap memiliki akibat hukum apabila dilakukan pencatatan perkawinan demikian pula dibuat batasan usia minimal untuk melangsungkan perkawinan. Kedua, dengan membuat aturan tambahan, yakni dengan membuat aturan yang tidak pernah dibicarakan dalam fikih klasik. Ketiga, membudayakan talfiq, yaitu meramu berbagai pendapat mujtahid kemudian diambil kesimpulan yang diduga kuat kebenaran dalilnya. ${ }^{19}$

${ }^{18}$ Harun Nasution, Islam Rasional: Gagasan dan Pemikiran, (Bandung: Mizan, 1996), hlm. 198

${ }_{19}$ Penjelasan ini dapat dilihat Amir Syarifuddin, Meretas Kebekuan Ijtihad: Isuisu Penting Hukum Islam Kontemporer di Indonesia, (Jakarta: Ciputat Press, 2002), hlm. 76-89 
Al-Fikra: Jurnal Ilmiah Keislaman, Vol. 7, No. 2, Juli-Desember 2008

Yusuf Qardhawi berpendapat bahwa ijtihad itu harus selalu ada mengingat begitu komplitnya persoalan yang dihadapi umat Islam dewasa ini. Untuk ini ia mengutip pendapat golongan Hanbali yang menyebutkan bahwa tidak boleh pada setiap masa vakum dari seorang mujtahid yang dapat dijadikan rujukan oleh masyarakat dalam persoalan-persoalan yang muncul di tengah-tengah mereka. ${ }^{20}$ Lebih lanjut Yusuf Qardhawi menyebutkan bahwa konsep ijtihad yang paling relevan sekarang ini adalah ijtihad intiqa'i dan ijtihad insya'i.21

\section{Kesimpulan}

Dari pemaparan kajian tentang filosofis fikih Irak dan hijaz seperti yang telah diuraikan di atas bahwa adanya fikih (pemahaman hukum Islam) yang dikelompokkan kemudian dengan istilah fikih Irak dan Hijaz muncul setelah wafatnya rasulullah saw. karena pada masa rasul setiap permasalahan yang muncul cukup dan dapat diselesaikan dengan penjelasan nabi.

Adapun lahirnya kedua kubu fikih Irak dan Hijaz ini adalah merupakan realita dan keharusan sejarah perkembangan hukum Islam yang dianalisa dari tiga faktor besar, yaitu; merupakan warisan intelektual, faktor struktural dan faktor kultural.

Sedangkan karakter berpikir yang menonjol adalah bahwa fikih Irak lebih berorientasi pada penggunaan rasio dan melakukan ijtihad dibandingkan dengan penggunaan hadis ataupun fatwa-fatwa sahabat. Sedangkan fikih Hijaz justru sebaliknya, yakni lebih berorientasi merujuk pada hadis-hadis yang ada serta fatwa-fatwa sahabat bila dibandingkan dengan penggunaan rasio. Meskipun demikian karakter ini hanyalah upaya untuk menarik benang merah antara kedua aliran tersebut yang merupakan karakteristik gaya intelektual daerah itu.

20 Yusuf Qardhawi, Alijitihad al-Mu'ashir baina al-Indibath wa al-Infirath, alih bahasa oleh Abu Barzani, (Surabava: Risalah Gusti, 1995), hlm. 23

21 Ijtihad intiqa'i adalah memilih satu pendapat dari beberapa pendapat terkuat yang terdapat pada warisan fikih Islam yang penuh dengan fatwa dan keputusan hukum. Ijtihad insya'i aadalah pengambilan konklusi hukum baru dari suatu persoalan yang belum pernah dikemukakan oleh ulama terdahulu, baik persoalan klasik maupun persoalan kontemporer.
Khairuddin, Filosofis Fikih Rasional dalam Islam

Sedangkan pada peringkat individu, cukup banyak dari masing-masing daerah yang tidak mengikuti karakteristik umum itu. Sebagai bukti, di kalangan orang-orang Hijaz terdapat seorang sarjana yang bernama Rabi'ah yang tergolong kelompok penalaran, demikian pula di kalangan sarjana Irak muncul seorang sarjana penganut dan pembela kelompok riwayat yang sangat tegar, yaitu Ahmad ibn Hanbal.

\section{Bibliografi}

Abdurrahman, Shariah The Islamic Law, alih bahasa oleh Basri Iba Asghari dan Wadi Masturi, (Jakarta: Rineka Cipta, 1993)

Bek, Hudhary, Tarikh al-Tasyri' al-Islamy, (Beirut: Daar al-Fikr, 1995).

Ghazali, Abu Hamid Muhammad ibn Muhammad, Al-Mustashfa min 'ilm al-Ushul, (Beirut: Daar al-Fikr, t.th.).

Hanafi, Ahmad, Pengantar dan Sejarah Hukum Islam, (Jakarta: Bulan Bintang, 1991).

Hasan, Ahmad, The Early Develovment of Islamic Jurisprudence, alih bahasa oleh Agah Garnadi, (Bandung: Pustaka, 1984).

Ibn Hazm, Abu Muhammad Ali ibn Ahmad ibn Sa'id, Al-Ihkam fi Ushul al-Abkam, (Beirut: Daar al-Kutub al-Ilmiah, t.th).

Ibn Katsir, al-Hafidz Imaduddin Abu al-Fida' Ismail, Tafsir al-Qur'an al-'Az̧him, Jilid 2, (Cairo: Maktabah Mishr, t.th).

Madjid, Nurchalish, Sejarah Awal Penyusunan dan Pembakuan Hukum Islam, dalam; Budhy Munawar Rachman (ed), Kontekstualisasi Doktrin Islam Dalam Sejarah, (Jakarta: Yayasan Paramadina, 1994).

Nasution, Harun, Islam Rasional: Gagasan dan Pemikiran, (Bandung: Mizan, 1996).

Qardhawi, Yusuf, AliIjtibad al-Mu'ashir baina al-Indibath wa al-Infirath, alih bahasa oleh Abu Barzani, (Surabaya: Risalah Gusti, 1995). 
Al-Fikra: Jurnal Ilmiah Keislaman, Vol. 7, No. 2, Juli-Desember 2008

Qurthubiy, Abu Abdillah Muhammad ibn Ahmad al-Anshariy, AlJami' li Abkam al-Qur'an, Jilid 4, Juz 8, (Beirut: Daar al-Fikr, 1994).

Shiddieqy, Muhammad Hasbi, Pengantar Hukum Islam I, (Jakarta: Bulan Bintang, 1980).

Sirry, Mun'im A., Sejarah Fikih Islam Sebuah Pengantar, (Surabaya: Risalah Gusti, 1996).

Syah, Ismail Muhammad dkk, Filsafat Hukum Islam, (Jakarta: Bumi Aksara, 1992).

Syarifuddin, Amir, Meretas Kebekuan Ijtihad: Isu-isu Penting Hukum Islam Kontemporer di Indonesia, (Jakarta: Ciputat Press, 2002).

Yanggo, Huzaemah Tahido, Pengantar Perbandingan Mą̧ab, Jakarta: Logos, 1997). 